\title{
Modelling the Impact of Key Pests of Watermelon on its Performance Using Linear Regression Models
}

\author{
Emmanuel OKRIKATA ${ }^{1, *}$, Emmanuel Oludele OGUNWOLU ${ }^{2}$ and \\ Ngozi Ifeoma ODIAKA ${ }^{3}$ \\ ${ }^{I}$ Department of Biological Sciences, Federal University Wukari, Taraba State, Nigeria \\ ${ }^{2}$ Department of Crop and Environmental Protection, Federal University of Agriculture Makurdi, Benue \\ State, Nigeria \\ ${ }^{3}$ Department of Crop Production, Federal University of Agriculture Makurdi, Benue State, Nigeria
}

( Corresponding author's e-mail: eokrikata@gmail.com)

Received: 20 October 2019, Revised: 3 May 2020, Accepted: 5 June 2020

\begin{abstract}
Despite the economic, health, and nutritional values of watermelon, insect pests remain a key limitation to its production globally. However, there has, hardly been any research that has statistically modeled the impact of insect pests on its performance. Therefore, this study aims to determine the relationship between the performance of watermelon and the density of its key pests with the aid of correlation and linear regression models, thereby presenting models for forecasting crop performance visà-vis pest density for optimum pest management. Data were collected from $40 \mathrm{~m}^{2}$ plots grouped into 4 replicates (10 plots/replicate) in field experiments (arranged in a randomized complete block design) in the early- and late-sown crops of 2016 and 2017 in the Research Farm of Federal University, Wukari, Nigeria. Plant survival rate $(\%)$ negatively and significantly $(\mathrm{P} \leq 0.05)$ correlated with each of mean number leaf-feeding beetles $\left(\mathrm{r}=-0.80, \mathrm{R}^{2}=63.5 \%, Y=92.023-3.145 x ; \mathrm{r}=-0.79, \mathrm{R}^{2}=62.1 \%, Y=\right.$ $95.986-5.975 x)$, A. gossypii density $\left(\mathrm{r}=-0.67, \mathrm{R}^{2}=44.9 \%, Y=184.048-50.444 x ; \mathrm{r}=-0.65, \mathrm{R}^{2}=42.4\right.$ $\%, Y=131.852-14.618 x)$, and $B$ tabaci density $\left(\mathrm{r}=-0.67, \mathrm{R}^{2}=45.2 \%, Y=188.832-11.138 x ; \mathrm{r}=\right.$ $\left.-0.66, \mathrm{R}^{2}=43.3 \%, Y=178.738-3.701 x\right)$ in both the early- and late-sown crop of 2016 , respectively, with a similar trend in those of 2017. All parameters significantly $(\mathrm{P} \leq 0.05)$ fitted the linear regression model. Densities of all major pests consistently correlated negatively and significantly with fruit yield. Student's t-test detected significant differences between the early- and late-sown crops of both years. We therefore conclude that watermelon experiences multiple pest infestations whose compositions and intensities vary between seasons, and that their influence on agronomic performance, as shown by the coefficient of determination $\left(\mathrm{R}^{2}\right)$ values (which were indicative of the reliability of the models with respect to the effect of pests on crop performance), were largely close or $>50 \%$.
\end{abstract}

Keywords: Flower sex ratio, Generalized linear regression, Leaf-feeding beetles, Leaf injury, Plant survival rate

\section{Introduction}

Across the tropics and Mediterranean regions of the world, watermelon [Citrullus lanatus Thunb. (Cucurbitaceae)] remains a key fruit vegetable, as it is cultivated on about $6.8 \%$ of earth field used for the production of vegetables [1]. Regardless of the high economic, health, and nutritional values of the crop, arthropod pests, particularly insects, remain a major limitation to its production [2] and crop performance has been shown to be suppressed by pest infestations $[3,4]$. Around the world, insect species that are sap sucking, fruit feeding, and leaf eating are widespread, and have been reported to infest watermelon 
http://wjst.wu.ac.th

throughout its growth stages [5,6]. The most abundant insect pest species for watermelon in the study site (Wukari, Nigeria) are Aulacophora africana Weise, Asbecesta nigripennis Weise, Asbecesta transversa Allard, Monolepta nigeriae Bryant, Epilachna chrysomelina Fab. (leaf-feeding beetles); Aphis gossypii L., Bemisia tabaci Genn. (sap-sucking insects); Bactrocera cucurbitae Coq., Helicoverpa armigera Hub. (fruit-boring insects) [7].

Evaluating the influence of pests on crop agronomic performance has been found to be very useful in pest modeling and forecasting [8,9]. However, despite the fact that yield losses of up to $100 \%$ due to insect pest infestations have been documented in watermelon [2], there has hardly been any study that has presented a model which could be used for predicting injury, survival, and eventual yield, vis-à-vis key pest pressure. Since crop pests are inherently part of every agroecosystem, estimating their contributions to crop performance is very important [10], and this area of investigation is currently receiving high attention in the field of pest management. The use of generalized linear regression has been shown to be proper and is widely acceptable in detecting the relationships between factors [11].

Therefore, the aim of this study is to determine the relationship between the agronomic performance of watermelon and the density of its major insect pests using correlation and linear regression models. This will aid forecasting of crop performance in relation to pest density for optimum pest management, as well as provide base-line information for further studies.

\section{Materials and methods}

\section{Study site}

The field experiments were conducted in the Research Farm of Federal University Wukari, Nigeria, in the 2016 and 2017 early- and late-cropping seasons. Wukari, which is located at N7 50'37', E9 ${ }^{\circ} 46^{\prime} 31^{\prime}$, has an altitude of $187 \mathrm{~m}$ above sea level, an average annual temperature of $26.8^{\circ} \mathrm{C}$, and an average annual rainfall of $1,205 \mathrm{~mm}$. The study area experiences a warm tropical climate characterized by wet and dry seasons. The wet season starts in April and ends in October, with peaks in June and September [12].

\section{The data}

The data used for this study is available in the research published in [7]. The experimental design and treatments applied are also detailed in [7], in which forty $5 \mathrm{~m}$ long $\times 8 \mathrm{~m}$ wide plots $\left(40 \mathrm{~m}^{2}\right)$ were demarcated on a 0.21 hectare of field during the 2016 and 2017 early- and late-cropping seasons. The plots were grouped into 4 replications of 10 treatments, arranged in a Randomized Complete Block Design (RCBD).

The treatments were applications of $0.5 \%$ Cypermethrin $30 \mathrm{~g} / \mathrm{L}+$ Dimethoate $250 \mathrm{~g} / \mathrm{L}$ EC (Cyperdiforce $^{\mathbb{R}}$ ) [produced by Jubaili Agrotec Ltd.] at $200 \mathrm{~L} /$ ha spray output at: seedling stage (S); midvegetative stage $(\mathrm{V})$; mid-flowering stage $(\mathrm{F})$; and mid-fruiting stage $(\mathrm{FR})$, and at the following combinations of stages: $-\mathrm{S}+\mathrm{V}+\mathrm{F}$; $\mathrm{S}+\mathrm{V}+\mathrm{FR}$; $\mathrm{S}+\mathrm{F}+\mathrm{FR} ; \mathrm{V}+\mathrm{F}+\mathrm{FR}$; and $\mathrm{S}+\mathrm{V}+\mathrm{F}+\mathrm{FR}$. An unsprayed plot, which served as the control (CT), was also included.

Mancozeb $80 \%$ WP. $\left(Z_{\text {eb-care }}{ }^{\circledR}\right.$ ), a preventive contact fungicide, was applied at the rate of $2 \mathrm{~kg} / \mathrm{ha}$ at the vegetative, flowering, and fruiting stages. The field was left for natural infestation, while manual weeding was done when due.

\section{Data collected}

\section{Assessment of insect population}

Sampling of insect species commenced at the $2^{\text {nd }}$ week after planting (WAP), and thereafter at weekly intervals until maturity of fruit (collections were made between 1,600 and 1,800 h), as described in [7]. Leaf feeding beetles and Helicoverpa armigera larvae were sampled using a shoulder-mounted suction sampler having a $10 \mathrm{~cm}$ diameter inlet cone (Burkard Scientific Ltd., Uxbridge, UK.) which was swept through a $5 \mathrm{~m}$ length of the middle row of each plot at an approximate walking speed of $1 \mathrm{~m} / \mathrm{s}$, as also shown in [7]. 
http://wjst.wu.ac.th

Whiteflies (Bemisia tabaci Genn.) were sampled using a $15 \times 15 \mathrm{~cm}^{2}$ yellow sticky board waved across a $5 \mathrm{~m}$ length of the middle row of each plot on shaking the plants, as described by [6,7]. Estimates of population densities of aphids (Aphis gossypii Glove) was made by assessing the colony size on 12 randomly selected leaves/plot using a scale from $0-9$ [where $\mathbf{0}=$ no aphids; $\mathbf{1}=1-4$ aphids; $\mathbf{2}=5-20$ aphids; $\mathbf{3}=21-100$ aphids; $\mathbf{4}=101-500$ aphids, and $\mathbf{5} \geq 500$ aphids]. Fruits infested by fruit fly were isolated and counted in each plot. Infested fruits were split open and the number of fruit fly larvae therein counted and expressed as number of fruit fly larvae/fruit.

Samples of dominant insects collected were killed in ethyl acetate in a killing jar, preserved in $70 \%$ ethanol, and then identified at the Insect Museum of Ahamadu Bello University, Zaria, Nigeria. Immature stages were reared to adult in the laboratory before identification, as shown in [7].

\section{Assessment of leaf injury and plant survival}

At 3, 6, and 9 WAP, a random sample of 15 leaves/plot were taken, and the proportion damaged was recorded following the method described by [13], and as adopted in [7]. Fifteen randomly selected leaves/plot were similarly scored for severity of injury on a scale of $0-4$, where;

$\mathbf{0}=0 \%$ leaf area injured

$\mathbf{1}=1-25 \%$ leaf area injured

$\mathbf{2}=26-50 \%$ leaf area injured

$\mathbf{3}=51-75 \%$ leaf area injured

$4=76-100 \%$ leaf area injured [13].

The individual scores obtained per plot were then converted to attack severity (\%) using the equation described by [7]. The plant survival rate (\%) was computed by dividing the final number of individual plants/plot by the number of individual plants/plot at 10 days after planting and multiplying the outcome by 100 .

\section{Assessment of marketable fruit yield}

Fruits in a plot were harvested twice at 10 day intervals, counted, weighed, and sorted into marketable and unmarketable categories. The latter comprised fruits that were discolored, misshapen, cracked, insect damaged, and infected with blossom end rot. The proportion of the marketable fruits was then computed as described in [7].

\section{Modelling}

The relationships between leaf-feeding beetles and leaf injury indices, between dominant insect pests and plant survival, and between dominant insect pests and marketable fruit yield were determined by Pearson's correlation and linear regression $(Y=c+m x$, where $\mathrm{y}$ is the dependent variable, $c$ is the intercept for a given line, $m$ is slope, and $x$ is the independent variable) analyses. Two-tailed pairedsamples Student's t-test was then used for comparing the parameters between the early- and late-sown crops. This was done using the means of the 4 replicates for each treatment and data set collected. The analyses were done using IBM $^{\circledR}$ SPSS $^{\circledR}$ version 23.0 (SPSS Inc., Chicago, Illinois) which was licensed in 2015. However, before running the aforementioned parametric tests, numerical data were transformed to $\sqrt{x}+0.5$, while data in percentages were transformed to arcsine. This was done to normalize them and to meet the assumptions of the parametric tests. However, the raw data were further subjected to Shapiro and Wilk's test to confirm their normality at $\mathrm{P}>0.05[7,14]$.

\section{Results and discussion}

After appropriate transformations, data collected were found to be approximately normally distributed $(\mathrm{P}>0.05)$ using the Shapiro and Wilk's test $[7,14]$. In 2016, the results showed positive and significant correlation of leaf-feeding beetle density with proportion of damaged leaves $(\mathrm{r}=0.94, Y=$ $1.202+4.169 x$ for early- and $\mathrm{r}=0.91, Y=5.015+2.545 x$ for late-sown crop), and severity of leaf injury $(\mathrm{r}=0.96, Y=-6.200+3.082 x$ and $\mathrm{r}=0.93, Y=0.973+1.839 x$, respectively) (Table 1). Leaf-beetles influenced a high proportion of the variation in both parameters, as shown by the $\mathrm{R}^{2}$ values (which were 
http://wjst.wu.ac.th

indicative of the reliability of the models with respect to the effect of pests on crop performance) of 88.4 and $92.1 \%$, respectively. Plant survival rate $(\%)$ negatively and significantly $(\mathrm{P} \leq 0.05)$ correlated with each of mean number leaf-feeding beetles $(\mathrm{r}=-0.80, \mathrm{Y}=92.023-3.145 x$ and $\mathrm{r}=-0.79, Y=95.986$ $-5.975 x)$, A. gossypii density $(\mathrm{r}=-0.67, Y=184.048-50.444 x$ and $\mathrm{r}=-0.65, Y=131.852-14.618 x)$, and $B$ tabaci density $(\mathrm{r}=-0.67, Y=188.832-11.138 x$ and $\mathrm{r}=-0.66, Y=178.738-3.701 x)$ in both the early- and late-sown crops, respectively. The $\mathrm{R}^{2}$ values were $63.5,44.9$ and $45.2 \%$ in the early-sown, and $62.1,42.4$ and $43.3 \%$ in the late-sown crops, respectively. Plant survival was less influenced by density of $H$. armigera larvae $\left(\mathrm{r}=-0.64, \mathrm{R}^{2}=40.9 \%, Y=114.096-6.341 x\right)$ in the late-sown crop. All parameters analyzed significantly $(\mathrm{P} \leq 0.05)$ fit the linear regression model (Table 1). In 2017, the results presented in Table 2 largely followed a trend similar to that of the preceding year.

Table 1 Linear regression and correlation analysis between leaf injury indices, plant survival, and major watermelon pests on the early- and late-sown crop in 2016.

\begin{tabular}{|c|c|c|c|c|c|}
\hline Variables & $\begin{array}{c}\text { Correlation } \\
\text { coefficient } \\
(\mathbf{r}) \\
\end{array}$ & $\begin{array}{l}\text { Regression equation }^{\mathrm{e}} \\
(Y=c+m x)\end{array}$ & $\begin{array}{c}\text { Coefficient of } \\
\text { determination }\left(\mathbf{R}^{2}\right)\end{array}$ & F-value & $\begin{array}{c}p \text {-value } \\
\text { for } R^{2}\end{array}$ \\
\hline \multicolumn{6}{|l|}{2016 early } \\
\hline $\mathrm{PLI}^{\mathrm{a}} \times \mathrm{LFB}^{\mathrm{b}}$ & 0.94 & $Y=1.202+4.169 x$ & 0.884 & 60.85 & $0.000 * * *$ \\
\hline $\mathrm{SLI}^{\mathbf{c}} \times \mathrm{LFB}^{\mathrm{b}}$ & 0.96 & $Y=-6.200+3.082 x$ & 0.921 & 93.21 & $0.000 * * *$ \\
\hline $\mathrm{PS}^{\mathbf{d}} \times \mathrm{LFB}^{\mathbf{b}}$ & -0.80 & $Y=92.023-3.145 x$ & 0.635 & 13.89 & $0.006 * *$ \\
\hline $\mathrm{PS} \times A$. gossypii & -0.67 & $Y=184.048-50.444 x$ & 0.449 & 6.52 & $0.034 *$ \\
\hline $\mathrm{PS} \times$ B. tabaci & -0.67 & $Y=188.832-11.138 x$ & 0.452 & 6.61 & $0.033 *$ \\
\hline \multicolumn{6}{|l|}{2016 late } \\
\hline $\mathrm{PLI} \times \mathrm{LFB}$ & 0.91 & $Y=5.015+2.545 x$ & 0.831 & 38.99 & $0.000 * * *$ \\
\hline $\mathrm{SLI} \times \mathrm{LFB}$ & 0.93 & $Y=0.973+1.839 x$ & 0.866 & 51.33 & $0.000 * * *$ \\
\hline $\mathrm{PS} \times \mathrm{LFB}$ & -0.79 & $Y=95.986-5.975 x$ & 0.621 & 13.32 & $0.007 * *$ \\
\hline $\mathrm{PS} \times A$. gossypii & -0.65 & $Y=131.852-14.618 x$ & 0.424 & 5.90 & $0.041 *$ \\
\hline $\mathrm{PS} \times$ B. tabaci & -0.66 & $Y=178.738-3.701 x$ & 0.433 & 6.10 & $0.039 *$ \\
\hline $\mathrm{PS} \times$ H.armigera larvae & -0.64 & $Y=114.096-6.341 x$ & 0.409 & 5.53 & $0.047 *$ \\
\hline
\end{tabular}

${ }^{a}$ PLI - Proportion of leaves injured (\%)

${ }^{b}$ LFB - Leaf-feeding beetles (mean of Asbecesta nigripennis, Asbecesta transversa, Aulacophora africana, Monolepta nigeriae, and Epilachna chrysomelina)

${ }^{\mathbf{c}} \mathrm{SLI}$ - Severity of leaf injury (\%)

${ }^{\mathrm{d}} \mathrm{PS}$ - Plant survival rate $(\%)$

${ }^{\mathrm{e}} Y=c+m x$. Where $Y$ is the dependent variable, $c$ is the intercept for a given line, $m$ is slope, and $x$ is the independent variable

$\mathrm{df}($ degree of freedom $)$ : Regression $=1$, Residual $=8$, Total $=9$

$*$ significantly different $(\mathrm{P} \leq 0.05)$

$* *=$ significantly different $(\mathrm{P} \leq 0.01)$

$* * *=$ significantly different $(\mathrm{P} \leq 0.001)$

$\mathrm{ns}=$ not significantly different $(\mathrm{P}>0.05)$ 
http://wjst.wu.ac.th

Densities of all major pests were negatively and significantly correlated with fruit yield in both the early- and late-sown crops of 2016 and 2017 (Tables 3 and 4). The coefficient of determination $\left(\mathrm{R}^{2}\right)$ for leaf-feeding beetles, A. gossypii, B. tabaci, and B. cucurbitae larvae were 78.6, 77.2, 73.5 and 81.9 \%, respectively, in the early-sown crop, and $81.2,80.9,78.9$ and $86.6 \%$ in the late-sown crop. H. armigera was negatively $(r=-0.86)$ and significantly $(P=0.001)$ correlated with marketable fruit yield with an $R^{2}$ value of $73.7 \%$ (Table 3). The $\mathrm{R}^{2}$ values for the 2017 cropping season ranged from 0.720 to 0.831 in the early-sown crop and from 0.600 to 0.846 in the late-sown crop. H. armigera (in the late-sown crop) was also negatively $(-0.850)$ and significantly $(\mathrm{P}=0.002)$ correlated with marketable fruit yield, with $\mathrm{R}^{2}$ values of 0.723 (Table 4).

Student's t-test detected significant differences between the early- and late-sown crops in both 2016 and 2017. Leaf-feeding beetle density, proportions of leaves injured, severity of leaf injury, B. cucurbitae larvae/fruit, and flower sex ratio were significantly $(t \alpha \leq 0.05)$ higher in the early-sown crops, while $A$. gossypii, B. tabaci density, main vine length $(\mathrm{cm})$ at 9 WAP, number of leaves at 9 WAP, number of fruits/ha, and fruit yield/ha were significantly $(t \alpha \leq 0.05)$ higher in the late-sown crops in both 2016 and 2017 (Tables 5 and 6).

Table 2 Linear regression and correlation analysis between leaf injury indices, plant survival, and major watermelon pests on the early- and late-sown crop in 2017.

\begin{tabular}{|c|c|c|c|c|c|}
\hline Variables & $\begin{array}{c}\text { Correlation } \\
\text { coefficient } \\
(\mathbf{r}) \\
\end{array}$ & $\begin{array}{l}\text { Regression equation }^{\mathrm{e}} \\
\quad(Y=c+m x)\end{array}$ & $\begin{array}{c}\text { Coefficient of } \\
\text { determination } \\
\left(\mathbf{R}^{2}\right)\end{array}$ & F-value & $\begin{array}{l}p \text {-value } \\
\text { for } R^{2}\end{array}$ \\
\hline \multicolumn{6}{|l|}{2017 early } \\
\hline $\mathrm{PLI}^{\mathbf{a}} \times \mathrm{LFB}^{\mathbf{b}}$ & 0.94 & $Y=5.161+4.118 x$ & 0.883 & 60.69 & $0.000 * * *$ \\
\hline $\operatorname{SLI}^{\mathbf{c}} \times \operatorname{LFB}^{\mathbf{b}}$ & 0.96 & $Y=-6.925+3.373 x$ & 0.922 & 94.74 & $0.000 * * *$ \\
\hline $\mathrm{PS}^{\mathbf{d}} \times \mathrm{LFB}^{\mathrm{b}}$ & -0.78 & $Y=89.346-3.029 x$ & 0.612 & 12.61 & $0.008 * *$ \\
\hline $\mathrm{PS} \times A$. gossypii & -0.66 & $Y=130.731-15.662 x$ & 0.433 & 6.13 & $0.039 *$ \\
\hline $\mathrm{PS} \times$ B. tabaci & -0.72 & $Y=252.059-11.475 x$ & 0.511 & 8.34 & $0.020^{*}$ \\
\hline \multicolumn{6}{|l|}{2017 late } \\
\hline PLI $\times$ LFB & 0.90 & $Y=9.774+2.363 x$ & 0.817 & 36.51 & $0.000 * * *$ \\
\hline \multirow[t]{2}{*}{$\mathrm{SLI} \times \mathrm{LFB}$} & 0.93 & $Y=1.073+2.005 x$ & 0.864 & 50.64 & $0.000 * * *$ \\
\hline & -0.84 & $Y=95.845-6.263 x$ & 0.703 & 18.80 & $0.002 * *$ \\
\hline \multicolumn{6}{|l|}{$\mathrm{PS} \times \mathrm{LFB}$} \\
\hline $\mathrm{PS} \times A$. gossypii & -0.57 & $Y=316.092-41.351 x$ & 0.320 & 3.77 & $0.088^{\mathrm{ns}}$ \\
\hline $\mathrm{PS} \times$ B. tabaci & -0.70 & $Y=188.724-4.014 x$ & 0.492 & 7.74 & $0.024 *$ \\
\hline $\mathrm{PS} \times H$. armigera larvae & -0.73 & $Y=133.196-7.303 x$ & 0.531 & 9.07 & $0.017 *$ \\
\hline
\end{tabular}

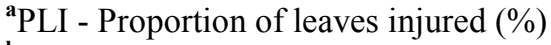

${ }^{b}$ LFB - Leaf-feeding beetles (mean of Asbecesta nigripennis, Asbecesta transversa, Aulacophora africana, Monolepta nigeriae, and Epilachna chrysomelina)

${ }^{\mathbf{c}} \mathrm{SLI}$ - Severity of leaf injury (\%)

${ }^{\mathrm{d}} \mathrm{PS}$ - Plant survival rate $(\%)$

${ }^{\mathrm{e}} Y=c+m x$. Where $Y$ is the dependent variable, $c$ is the intercept for a given line, $m$ is slope, and $x$ is the independent variable

df (degree of freedom): Regression $=1$, Residual $=8$, Total $=9$

$*$ significantly different $(\mathrm{P} \leq 0.05)$

$* *=$ significantly different $(\mathrm{P} \leq 0.01)$

$* * *=$ significantly different $(\mathrm{P} \leq 0.001)$

${ }^{\mathrm{ns}}=$ not significantly different $(\mathrm{P}>0.05)$ 
http://wjst.wu.ac.th

Table 3 Linear regression and correlation analysis between marketable fruit yield and major watermelon pests on the early- and late-sown crop in 2016.

\begin{tabular}{|c|c|c|c|c|c|}
\hline Variables & $\begin{array}{l}\text { Correlation } \\
\text { coefficient } \\
(r)\end{array}$ & $\begin{array}{l}\text { Regression equation }{ }^{\mathrm{c}} \\
\quad(Y=c+m x)\end{array}$ & $\begin{array}{c}\text { Coefficient of } \\
\text { determination } \\
\left(\mathbf{R}^{2}\right)\end{array}$ & F-value & $\begin{array}{l}p \text {-value } \\
\text { for } R^{2}\end{array}$ \\
\hline $\begin{array}{l}2016 \text { early } \\
\text { MFY }^{\mathrm{a}} \times \mathrm{LFB}^{\mathrm{b}}\end{array}$ & -0.89 & $Y=36.220-2.316 x$ & 0.786 & 30.18 & $0.001 * *$ \\
\hline $\mathrm{MFY} \times A$. gossypii & -0.88 & $Y=120.039-43.786 x$ & 0.772 & 27.73 & $0.001 * *$ \\
\hline MFY $\times$ B. tabaci & -0.86 & $Y=121.079-9.394 x$ & 0.735 & 22.68 & $0.002 * *$ \\
\hline $\begin{array}{l}\text { MFY } \times B \text {. } \\
\text { cucurbitae larvae }\end{array}$ & -0.91 & $Y=43.062-2.539 x$ & 0.819 & 40.67 & $0.000 * * *$ \\
\hline $\begin{array}{l}2016 \text { late } \\
\text { MFY } \times \text { LFB }\end{array}$ & -0.90 & $Y=46.324-5.879 x$ & 0.812 & 35.91 & $0.000 * * *$ \\
\hline $\mathrm{MFY} \times A$. gossypii & -0.90 & $Y=94.662-17.357 x$ & 0.809 & 34.32 & $0.000 * * *$ \\
\hline $\mathrm{MFY} \times$ B. tabaci & -0.89 & $Y=147.458-4.299 x$ & 0.789 & 30.32 & $0.001 * *$ \\
\hline $\begin{array}{l}\text { MFY } \times B \text {. } \\
\text { cucurbitae larvae }\end{array}$ & -0.93 & $Y=48.115-8.642 x$ & 0.866 & 52.92 & $0.000 * * *$ \\
\hline $\begin{array}{l}\text { MFY } \times H \text {. armigera } \\
\text { larvae }\end{array}$ & -0.86 & $Y=72.076-7.323 x$ & 0.737 & 22.77 & $0.001 * *$ \\
\hline
\end{tabular}

${ }^{\mathrm{a}} \mathrm{MFY}$ - Marketable fruit yield

${ }^{\mathbf{b}}$ LFB - Leaf-feeding beetles (mean of Asbecesta nigripennis, Asbecesta transversa, Aulacophora africana, Monolepta nigeriae, and Epilachna chrysomelina)

${ }^{\mathrm{c}} Y=c+m x$. Where; $Y$ is the dependent variable, $c$ is the intercept for a given line, $m$ is slope, and $x$ is the independent variable

df $($ degree of freedom $)$ : Regression $=1$, Residual $=8$, Total $=9$

$*$ = significantly different $(\mathrm{P} \leq 0.05)$

$* *$ = significantly different $(\mathrm{P} \leq 0.01)$

$* * *=$ significantly different $(\mathrm{P} \leq 0.001)$

${ }^{\mathrm{ns}}=$ not significantly different $(\mathrm{P}>0.05)$ 
http://wjst.wu.ac.th

Table 4 Linear regression and correlation analysis between marketable fruit yield and major watermelon pests on the early- and late-sown crop in 2017.

\begin{tabular}{|c|c|c|c|c|c|}
\hline Variables & $\begin{array}{l}\text { Correlation } \\
\text { coefficient (r) }\end{array}$ & $\begin{array}{l}\text { Regression equation }^{c} \\
\quad(Y=c+m x)\end{array}$ & $\begin{array}{l}\text { Coefficient of } \\
\text { determination } \\
\left(\mathbf{R}^{2}\right)\end{array}$ & F-value & $\begin{array}{c}p \text {-value } \\
\text { for } \\
\mathbf{R}^{2}\end{array}$ \\
\hline \multicolumn{6}{|l|}{2017 early } \\
\hline $\mathrm{MFY}^{\mathbf{a}} \times \mathrm{LFB}^{\mathbf{b}}$ & -0.88 & $Y=36.121-2.267 x$ & 0.782 & 28.74 & $0.001 * *$ \\
\hline $\mathrm{MFY} \times A$. gossypii & -0.88 & $Y=76.670-13.841 x$ & 0.772 & 27.04 & $0.001 * *$ \\
\hline $\mathrm{MFY} \times$ B. tabaci & -0.85 & $Y=165.042-9.015 x$ & 0.720 & 20.54 & $0.002 * *$ \\
\hline MFY $\times$ B.cucurbitae larvae & -0.91 & $Y=38.624-2.535 x$ & 0.831 & 39.46 & $0.000 * * *$ \\
\hline \multicolumn{6}{|l|}{2017 late } \\
\hline MFY $\times$ LFB & -0.90 & $Y=46.464-5.796 x$ & 0.813 & 34.71 & $0.000 * * *$ \\
\hline $\mathrm{MFY} \times A$. gossypii & -0.78 & $Y=313.380-48.685 x$ & 0.600 & 12.01 & $0.009 * *$ \\
\hline $\mathrm{MFY} \times B$. tabaci & -0.90 & $Y=153.636-4.407 x$ & 0.801 & 32.25 & $0.000 * * *$ \\
\hline MFY $\times$ B. cucurbitae larvae & -0.92 & $Y=69.967-8.022 x$ & 0.846 & 53.02 & $0.000 * * *$ \\
\hline MFY $\times$ H. armigera larvae & -0.85 & $Y=86.293-7.328 x$ & 0.723 & 20.90 & $0.002 * *$ \\
\hline
\end{tabular}

${ }^{\mathrm{a}} \mathrm{MFY}$ - Marketable fruit yield

${ }^{\mathbf{b}}$ LFB - Leaf-feeding beetles (mean of Asbecesta nigripennis, Asbecesta transversa, Aulacophora africana, Monolepta nigeriae, and Epilachna chrysomelina)

${ }^{c} Y=c+m x$. Where $Y$ is the dependent variable, $c$ is the intercept for a given line, $m$ is slope, and $x$ is the independent variable

df $($ degree of freedom $)$ : Regression $=1$, Residual $=8$, Total $=9$

$*$ = significantly different $(\mathrm{P} \leq 0.05)$

$* *=$ significantly different $(\mathrm{P} \leq 0.01)$

$* * *=$ significantly different $(\mathrm{P} \leq 0.001)$

ns $=$ not significantly different $(\mathrm{P}>0.05)$

Details of the injuries caused by pests of crops leading to damage, and eventually yield losses, are available in the literature [8]. Relationships between yield losses and damages caused by pests can be well expressed using regression statistics [8,9]. Generalized linear regression models have been shown to be effective and reliable for detecting relationships between parameters [11] and are widely acceptable. The linear regression models generated by this study are highly reliable, as their coefficients of determination $\left(\mathrm{R}^{2}\right)$ were mostly significant $(\mathrm{P} \leq 0.05)$ and largely close or $>50 \%$. Hence, preliminary models are here presented for forecasting agronomic performance in the study area in the face of each of the key pest densities. This is especially important for determining the critical pest densities at which management strategies can be employed, with documented outrageous pesticide application, with its attendant health and environmental consequences, in the study area $[7,15]$. 
http://wjst.wu.ac.th

Table 5 Comparisons between early- and late-sown crop at Wukari in 2016.

\begin{tabular}{|c|c|c|c|c|c|c|}
\hline Variables & $\begin{array}{l}\text { Means for } \\
\text { early-sown }\end{array}$ & $\begin{array}{l}\text { Means for } \\
\text { late-sown }\end{array}$ & $\begin{array}{c}\text { Mean } \\
\text { difference }^{1}\end{array}$ & t-value & df & $p$-value \\
\hline Leaf-feeding beetles $^{2}$ & $9.52 \pm 1.79$ & $4.73 \pm 0.86$ & $4.79 \pm 0.93$ & 5.131 & 9 & $0.001 * *$ \\
\hline $\begin{array}{l}\text { Proportion of leaves } \\
\text { injured }(\%)\end{array}$ & $40.91 \pm 7.94$ & $17.06 \pm 2.40$ & $23.85 \pm 5.61$ & 4.251 & 9 & $0.002 * *$ \\
\hline Severity of leaf injury (\%) & $23.15 \pm 5.75$ & $9.68 \pm 1.69$ & $13.47 \pm 4.08$ & 3.303 & 9 & $0.009 * *$ \\
\hline A. gossypii & $2.42 \pm 0.94$ & $4.39 \pm 0.29$ & $-1.97 \pm 0.20$ & -10.011 & 9 & $0.000 * * *$ \\
\hline B. tabaci density & $11.38 \pm 0.43$ & $29.99 \pm 1.16$ & $-18.62 \pm 0.73$ & -25.402 & 9 & $0.000 * * *$ \\
\hline B. cucurbitae larvae/fruit & $11.27 \pm 1.61$ & $3.43 \pm 0.60$ & $7.84 \pm 1.01$ & 7.76 & 9 & $0.000 * * *$ \\
\hline $\begin{array}{l}\text { Main vine length }(\mathrm{cm}) \text { at } \\
9 \text { WAP }\end{array}$ & $201.73 \pm 24.57$ & $223.58 \pm 25.72$ & $-21.85 \pm 1.27$ & -17.262 & 9 & $0.000 * * *$ \\
\hline $\begin{array}{l}\text { Number of leaves/plant at } \\
9 \text { WAP }\end{array}$ & $137.10 \pm 31.33$ & $166.59 \pm 33.47$ & $-29.49 \pm 2.17$ & -13.605 & 9 & $0.000 * * *$ \\
\hline Plant Survival Rate (\%) & $62.07 \pm 7.07$ & $67.71 \pm 6.52$ & $-5.64 \pm 0.88$ & -6.387 & 9 & $0.000 * * *$ \\
\hline Flower sex ratio & $5.81 \pm 0.28$ & $5.41 \pm 0.27$ & $0.40 \pm 0.02$ & 20.25 & 9 & $0.000 * * *$ \\
\hline Total number of fruits/ha & $8871.3 \pm 1838.6$ & $10492.4 \pm 1964.6$ & $-1621.1 \pm 176.5$ & -9.186 & 9 & $0.000 * * *$ \\
\hline Fruit yield $\left(\right.$ tha $\left.^{-1}\right)$ & $17.67 \pm 4.92$ & $23.04 \pm 5.77$ & $-5.37 \pm 0.92$ & -5.827 & 9 & $0.000 * * *$ \\
\hline
\end{tabular}

1 - Values indicates means $( \pm \mathrm{SE})$ for early-sown minus means $( \pm \mathrm{SE})$ for late-sown

${ }^{2}=$ Mean of Asbecesta nigripennis, Asbecesta transversa, Aulacophora africana, Monolepta nigeriae, and Epilachna chrysomelina

$*$ significantly different $(\mathrm{P} \leq 0.05)$

$* *$ = significantly different $(\mathrm{P} \leq 0.01)$

$* * *=$ significantly different $(\mathrm{P} \leq 0.001)$

ns $=$ not significantly different $(\mathrm{P}>0.05)$

WAP - Weeks after planting

Throughout the 2-year intensive study, prevalence of $H$. armigera (a key fruit boring insect) in the early-season crop was low. The early-season crop was marked by high frequency and intensity of rainfall, which might not have been amenable for $H$. armigera colonization and population growth. Non-stationary climate has been reported to change the behavior of insects and their host plants [16]. These changes may be due to seasonal parameters or changes in physiological attributes. These alterations have given rise to inconsistent insect/weather parameter relationships [17]. There is, therefore, the need for extensive study of the influence of weather on population dynamics of the major pests of watermelon in order to aid pest forecasting. 
http://wjst.wu.ac.th

Table 6 Comparisons between early- and late-sown crop at Wukari in 2017.

\begin{tabular}{|c|c|c|c|c|c|c|}
\hline Variables & $\begin{array}{l}\text { Means for } \\
\text { early-sown }\end{array}$ & $\begin{array}{l}\text { Means for } \\
\text { late-sown }\end{array}$ & $\begin{array}{c}\text { Mean } \\
\text { difference }^{1}\end{array}$ & t-value & df & $p$-value \\
\hline Leaf-feeding beetles $^{2}$ & $9.69 \pm 1.83$ & $4.83 \pm 0.87$ & $4.86 \pm 0.96$ & 5.090 & 9 & $0.001 * *$ \\
\hline $\begin{array}{l}\text { Proportion of leaves } \\
\text { injured }(\%)\end{array}$ & $45.05 \pm 8.00$ & $21.18 \pm 2.28$ & $23.88 \pm 5.79$ & 4.122 & 9 & $0.003 * *$ \\
\hline Severity of leaf injury (\%) & $25.75 \pm 6.41$ & $10.75 \pm 1.88$ & $15.00 \pm 4.56$ & 3.290 & 9 & $0.009 * *$ \\
\hline A. gossypii & $4.52 \pm 0.30$ & $6.06 \pm 0.89$ & $-1.54 \pm 0.22$ & -7.164 & 9 & $0.000 * * *$ \\
\hline B. tabaci density & $16.74 \pm 0.44$ & $30.66 \pm 1.14$ & $-13.93 \pm 0.75$ & -18.649 & 9 & $0.000 * * *$ \\
\hline B. cucurbitae larvae/fruit & $9.65 \pm 1.68$ & $6.50 \pm 0.62$ & $3.16 \pm 1.07$ & 2.95 & 9 & $0.016^{*}$ \\
\hline $\begin{array}{l}\text { Main vine length }(\mathrm{cm}) \text { at } \\
9 \text { WAP }\end{array}$ & $189.38 \pm 22.30$ & $210.15 \pm 23.36$ & $-20.77 \pm 3.20$ & -6.488 & 9 & $0.000 * * *$ \\
\hline $\begin{array}{l}\text { Number of leaves/plant at } \\
9 \text { WAP }\end{array}$ & $128.91 \pm 29.42$ & $147.84 \pm 31.45$ & $-18.93 \pm 2.24$ & -8.445 & 9 & $0.000 * * *$ \\
\hline Plant Survival Rate (\%) & $60.00 \pm 7.07$ & $65.63 \pm 6.52$ & $-5.63 \pm 1.07$ & -5.219 & 9 & $0.001 * *$ \\
\hline Flower sex ratio & $5.88 \pm 0.29$ & $5.48 \pm 0.27$ & $0.41 \pm 0.02$ & 20.41 & 9 & $0.000 * * *$ \\
\hline Total number of fruits/ha & $8494.5 \pm 1790.6$ & $10079.6 \pm 1911.1$ & $-1585.2 \pm 171.1$ & -9.265 & 9 & $0.00 * * *$ \\
\hline Fruit yield $\left(\right.$ tha $\left.^{-1}\right)$ & $16.98 \pm 4.77$ & $22.20 \pm 5.60$ & $-5.22 \pm 0.89$ & -5.872 & 9 & $0.000 * * *$ \\
\hline
\end{tabular}

1 - Values indicates means $( \pm \mathrm{SE})$ for early-sown minus means $( \pm \mathrm{SE})$ for late-sown

${ }^{2}=$ Mean of Asbecesta nigripennis, Asbecesta transversa, Aulacophora africana, Monolepta nigeriae, and Epilachna chrysomelina

$*$ significantly different $(\mathrm{P} \leq 0.05)$

$* *=$ significantly different $(\mathrm{P} \leq 0.01)$

$* * *=$ significantly different $(\mathrm{P} \leq 0.001)$

ns $=$ not significantly different $(\mathrm{P}>0.05)$

WAP - Weeks after planting

It has been shown that leaf injury has serious implications for fruit quality and quantity, as the leaves play a key role in synthesizing sugar and in accumulating water in the fruit [18]. That herbivory suppresses reproductive performance of plants has been reported by $[8,19]$. They showed that defoliation of plant tissue by defoliators and allocation of resources for plant defense lowers the amount of resources which would have been allocated for reproduction and, eventually, yield. [20] found out that, even though leaf feeding beetles are all-season pests, they are most attractive to cucurbits during the seedling and vegetative stages of growth. The ability of leaf-eating beetles to compromise seedlings and/or bring about loss of plant stands and, eventually, yield has been reported by [21]. Our statistical analyses showed that, of the key pests of watermelon in the study area, the leaf-feeding beetle had the most suppressive influence on survival and, ultimately, yield. However, since the pattern of injury of the 5 major leaf beetle species (A. nigripennis, A. transversa, A. africana, M. nigeriae, and E. chrysomelina) are similar, it was difficult to isolate the most important leaf-eating beetle species, even though they were all found to be significantly higher in density on the early- than on the late-sown crop, with $A$. nigripennis and $M$. nigeriae being more predominant. 
http://wjst.wu.ac.th

\section{Conclusions}

The present study showed that watermelon experiences multiple pest infestations and their compositions and intensities vary between seasons, variably influencing agronomic performance, as indicated by the $\mathrm{R}^{2}$ values. Lower pest infestation (frequency and intensity) was also empirically shown to give rise to better growth indices, higher numbers of staminate and pistillate flowers with lower floral sex ratio, signifying higher numbers of female flowers and, consequently, higher yields. Preliminary models for predicting the crop performance in relation to the individual key pest densities are here also formulated.

\section{Acknowledgements}

This study is part of a Ph.D. thesis in Economic Entomology at Federal University of Agriculture, Makurdi, Nigeria. Many thanks to Mr. Ogunmola Adeniyi of the Statistics Department and Mr. Ekoja E. E. of the Department of Crop and Environmental Protection, Federal University of Agriculture, Makurdi, Nigeria, for their input in statistical analyses. The expertise of Mr. Ishaku Musa of the Insect Museum of Ahmadu Bello University, Zaria, Nigeria, in identifying samples of insects collected on watermelon is also appreciated.

\section{References}

[1] T Nordey, C Basset-Mens, HD Bon, T Martin, E Déletré, S Simon, L Parrot, H Despretz, J Huat, Y Biard, T Dubois and E Malézieux. Protected cultivation of vegetable crops in sub-Saharan Africa: Limits and prospects for smallholders: A review. Agr. Sus. Dev. 2017; 37, 53.

[2] S Shagufta. Fruits and vegetables production. African Publishing House, Ibadan, Nigeria, 2012.

[3] J Kranz. Interactions in pest complexes and their effects on yield. J. Plant Dis. Protec. 2005; 112, 366-85.

[4] EC Oerke. Crop losses to pests. J. Agr. Sci. 2006; 144, 31-43.

[5] AF Olaitan and TA Adebayo. Comparative efficacy of Tephrosia vogelii and Moringa oleifera against insect pests of watermelon. Int. Lett. Nat. Sci. 2015; 35, 71-8.

[6] E Okrikata, EO Ogunwolu and MU Ukwela. Diversity, spatial and temporal distribution of aboveground arthropods associated with watermelon in the Nigerian Southern Guinea Savanna. J. Insect Biodivers. Systemat. 2019; 5, 11-32.

[7] E Okrikata and E Ogunwolu. Determination of the critical period of cyper-diforce ${ }^{\circledR}$ treatment against arthropod fauna and productivity of watermelon. Iraqi J. Sci. 2019; 60, 1904-19.

[8] PD Esker, S Savary and N McRoberts. Crop loss analysis and global food supply: Focusing now on required harvests. $C A B$ Rev. 2012; 7, 1-14.

[9] JPM Whish, NI Herrmann, NA White, AD Moore and DJ Kriticos. Integrating pest population models with biophysical crop models to better represent the farming system. Environ. Model. Software 2015; 72, 418-25.

[10] M Donatelli, RD Magarey, S Bregaglio, L Willocquet, JPM Whish and S Savary. Modelling the impacts of pests and diseases on agricultural systems. Agr. Syst. 2017; 155, 213-24.

[11] JO Odhiambo, P Ngare, P Weke and RO Otieno. Modelling of COVID-19 transmission in Kenya using poisson regression model. J. Adv. Math. Compt. Sci. 2020; 35, 101-11.

[12] E Okrikata and OA Yusuf. Diversity and abundance of insects in Wukari, Taraba State, Nigeria. Int. Biol. Biomed. J. 2016; 2, 156-66.

[13] R Trusca, I Grozea and R Stef. Attractiveness and injury levels of adults by Diabrotica virgifera virgifera (Le Conte) on different host plant. J. Food Agr. Environ. 2013; 2, 773-6.

[14] SS Shapiro and MB Wilk. An analysis of variance test for normality (complete samples). Biometrika 1965; 52, 591-611.

[15] E Okrikata, EO Ogunwolu and MU Ukwela. Efficiency and economic viability of neem seed oil emulsion and cyper-diforce ${ }^{\circledR}$ insecticides in watermelon production within the Nigerian Southern Guinea Savanna zone. J. Crop Protec. 2019; 8, 81-101. 
http://wjst.wu.ac.th

[16] M Poornima. 2013, Effect of weather parameters on incidence of major pests and their natural enemies in few selected kharif and rabi crops. Ph.D. Thesis. University of Dhaward, Karnataka, India.

[17] JS Bale, GJ Masters, ID Hodkinson, C Awmack, TM Bezemer, VK Brown, J Butterfield, A Buse, JC Coulson, J Farrar, JEG Good, R Harrington, S Hartley, TH Jones, RI Lindroth, MC Press, I Symrnioudis, AD Watt and JB Whittaker. Herbivory in global climate change research: Direct effects of rising temperature on insect herbivores. Global Change Biol. 2002; 8, 1-16.

[18] MM Degri and HS Sharah. Field evaluation of two aqueous plant extracts on watermelon Citrullus lanatus (Thunb.) insect pest in Northern Guinea Savannah of Nigeria. Int. Lett. Nat. Sci. 2014; 14, 59-67.

[19] J Liu, S Legarrea and MR Kent. Tomato reproductive success is equally affected by herbivores that induce or that suppress defenses. Front. Plant Sci. 2017; 8, 2128.

[20] G Zehnder. Management of cucumber beetles and bacterial wilts of cucurbits. Alabama cooperative extension system. Alabama A and M University and, Auburn University, USA, 1997.

[21] TW Sappington, LS Hesler, KC Allen, RG Lutrell and SK Papiernik. Prevalence of sporadic insect pests of seedling corn and factors affecting risk of infestation. J. Int. Pest Mgt. 2018; 9, 1-27. 